

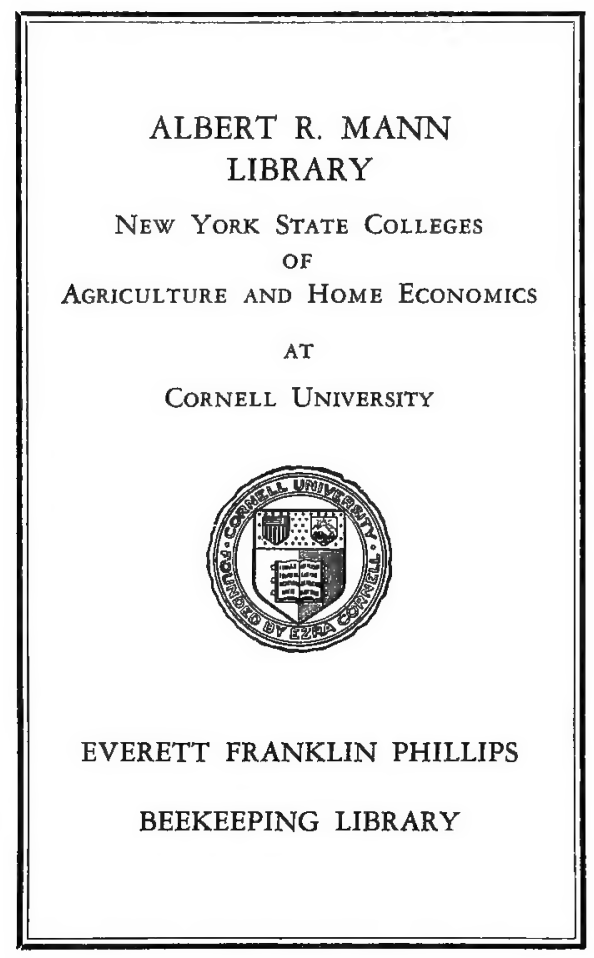




\title{
PROCEEDINGS
}

\section{TWENTY-FIRST ANNUAL MEETING}

\author{
OF
}

Society for Promotion Agricultural Science.

1900

Effects of Artificial Foundation on the Building of Honey Comb.

By ClARENCE P. GILLETTE, M. Sc., Agricultural College.

FT. COLLINS, COLORADO. 


\section{Cornell University Library}

The original of this book is in the Cornell University Library.

There are no known copyright restrictions in the United States on the use of the text. 
EFFECTS OF ARTIFICIAL FOUNDATIONS ON THE BUILDING OF HONEY COMB.

\author{
By Clarence P. Gillette, M. Sc., Agricultural College, \\ Ft. Collins, Colorado.
}

It is about a third of a century since thin sheets of wax were first successfully used to aid honey bees in the process of comb building. The plane sheet of thin wax that was then exployed has undergone a process of evolution until to-day comb foundation may be purchased with a base thinner than that naturally made by the bees and with comb cells extended to fully one-fourth their ordinary length in brood comb.

The objects in using artificial foundation are many. Perhaps its most important use is to determine the position of the comb in the hive. By its use it is possible to almost prevent the building of drone comb, and the tendency to swarm is lessened in consequence. Without foundation it would hardly be possible to produce a fine quality of comb honey in sections, such as charms the eye and tempts the appetite in store windows in almost every city and town in the land. The use of foundation in brood frames or sections is believed to lessen the expense in food and labor to the bee in building the comb.

The experiments here reported were undertaken to determine the effect that artificial foundations have upon the amount and quality of wax in the comb and to determine to what extent the secretion of wax by bees is economized by furnishing them wax in foundations.

While it is generally stated that bees use wax from forndations with which to build comb, it was thought best first to determine for a certainty whether or not this is done. At my request $\mathrm{Mr}$. C. B. Elliott of Denver manufactured for me a few sheets of foundation that were made jet black by mixing lampblack into the melted wax. This foundation was used in sections as starters for comb honey. The bees accepted the black foundation as well as any and drew out 
the comb cells upon it. The results were most conclusive and are shown in the photograph that $I$ hold in my hand, and also in this sample of the comb. In this section of comb it will be noticed that the black wax is drawn out into the cell walls nearly or quite to the ends and that the dark color becomes less and less from the midrib outward until it hardly shows at the extremity of the deeper cells. It will also be noticed that in the section where a short starter was used the blackened wax is extended downward for a considerable distance and also outward into the walls of the cells. As the color was imbedded into the wax of the foundation the experiment shows conclusively that the wax of the foundation is used in drawing out the comb, and in extending the midrib. As all the foundations used had short cell walls it was thought best next to determine whether or not the bees used wax from both the midrib and cell walls of the foundation or from the latter only. To determine whether or not wax was used from the midrib, samples of foundation were cast in plaster of Paris and cross-sections made. Then other samples were given to the bees for them to draw into comb. After the comb was built, it was also cast in plaster and sectioned with a sharp knife. Then careful measurements were made under a camera lucida of the thickness of both the foundation midrib and the midrib of comb built upon it. This was done in many instances and with foundations of very different weights, from the extra thin to the extra heavy. As a result it was found that the heavier foundations always had their midribs thinned, but never to the thinness of that of naturally built worker comb. It was also found that the foundations having midribs not exceeding $.17 \mathrm{~mm}$. in thickness were usually thinned little if at all; and in some cases where the midrib was thinner than in natural comb the bees plastered on wax and made it unusually thick. ${ }^{*}$ [Show photographs and comb samples].

That the short cell walls of the foundation were also thinned and used in comb building was evident at once on examining the bases of the cell walls of comb on foundation. See illustrations and comb samples.

What was true of heavy midribs was also true here. In cases where there was much wax in the short cell walls

\footnotetext{
*It is possible that the thickened places were due to complete perforations of the midrib.
} 
of the foundation, the bases of the cell walls of the comb were not thinned to the delicacy of the walls in natural comb. In cases where light foundations were used as the thin and extra thin super, and a rather low "high-wall" foundation manufactured by Mr. E. B. Weed, the walls were scarcely if at all heavier than in natural comb. In another foundation manufactured by $\mathrm{Mr}$. Weed and sold as "Extra deep-celled foundation" in which the walls were fully three-sixteenths of an inch long, the bees did not thin the walls well, usually leaving them decidedly heavier than the natural.

Another method of testing the effect of foundation upon the comb was also used. This was to take samples of comb of different thicknesses, some naturally built, and others built upon foundations, cut out blocks of known area, and then compare their weights. Occasionally a sample of comb on the very light foundations used for section honey were as light as the heavier samples of natural comb of the same thickness, but on no foundation did they average as light as the heavier samples of natural comb of the same thickness, and on no foundation did they average as light as the naturally built article.

On heavy foundations, without exception, the comb samples were heavier than those of the same size and thickness naturally built. When foundation as heavy as 11 grains to the square inch was used, the resulting comb, one inch thick, averaged 18,50 grains to the square inch, while naturally built worker comb of this thickness only averaged about 10 grains to the square inch. Even medium brood foundation gave comb that areraged 16.50 grains to the square inch when the comb was one inch thick.

So, while comb samples of the same thickness on different foundations, or even the naturally built comb, vary considerably in weight, it was found that all foundations used, from the extra thin to the extra heavy, resulted in a comb that averaged higher in weight than natural worker comb.

The wax of the foundation was used from both the midrib and short cell walls. The midrib is seldom, if ever, cut down to the thinness of that in natural comb, and if very thick, it is left very much heavier. If their is a large amount of wax in either the midrib or cell walls of the 
foundations the cell walls of the comb will also be heavier than the natural, particularly in their lower or inner portion. So the often repeated statement that bees always build cell walls of the same thickness no matter how much wax is in the foundation, is not correct. In fact, it was found that the increased weight of comb built on heavy foundations was due more to the excess of wax in cell walls than to the extra amount in the midrib.

One kind of foundation deserves special notice in this connection, and that is the extra deep-cell foundation already mentioned that was manufactured by Mr. E. B. Weed and which has been sold quite extensively for the past two years. The foundation is almost a marvel of mechanical skill. The walls of the cells are pressed out so as to give the foundation a thickness of fully five-sixteenths of an inch. The midrib is very thin but the cell walls are much heavier than those of natural comb. The idea of the manufacturer was that these cell walls would be thinned to the thickness of those in natural comb, but the bees did not so thin them in any of the examples I have studied. Usually $I$ have found them much thicker. In fact it is often the case that the walls are scarcely thinned at all. [See samples and photos]. A more shallow "deep-cell" foundation, also manufactured by Mr. Weed, and which is even more beautiful than the former, was worked by the bees into a comb that approximated very closely the natural in both lightness and friability. The walls of the cells are not so high but what the bees can reach to the bottom of them with their mandibles and pinch them to the thinness of walls in naturally built comb. [Show sample of foundation].

TO WHAT EXTENT DOES THE FOUNDATION LESSEN THE SECRETION OF WAX BY THE BEES?

Let us begin with the comb built on the heavier foundations and compare with the naturally built worker comb, to determine the effect on wax secretion.

Natural worker comb 1 inch thick weighed 10.00 grains to the square inch. The very heavy foundation alone weighed 11.00 grains or 1 grain more than is necessary to 
build the comb to that thickness. But when comb was built on this thick foundation, it weighed 18.50 grains, so that the bees added 7.50 grains to the square inch to the foundation that itself contained more wax than was necessary to build the comb. As natural comb weigbs but 10.00 grains to the square inch, the bees lacked but 2.50 grains of furnishing as much wax as they would have done if they had built the comb without the foundation. "It is seen that 11.00 grains of wax were furnished the bees in order to save them tne expense in food and labor of producing 2.50 grains.

In case of the medium brood foundation weighing 8.40 grains to the square inch, the result was similar. The bees needed to add but 1.60 grams to this to build the comb one inch thick, but they did add 8.10 grains, making a comb weighing 16.50 grains to the square inch. As the amount added in this case is only 1.90 grains less than the weight of the natural comb of the same thickness, it cost the whole weight of the foundation, or 8.40 grains, to save the bees from secreting 1.90 grains of wax.

As another illustration with this same foundation, take the samples drawn to .75 of an inch. The arerage weight would be 12.50 grains. This is 5.90 grains more than the weight of samples of natural comb drawn to the same thickness, and 4.10 grains more than the weight of the foundation alone, notwithstanding the fact that the foundation as given the bees contained 1.80 grains to the square inch more wax than was necessary to build natural comb to that thickness. In other words, the bees were furnished more wax than was necessary to build the comb threequarters of an inch thick, and yet they added to this amount more than nine-tenths as much wax as they would have used to build the comb without foundation.

Passing now to the Weed deep-cell foundation manufactured in 1898 , we find results fully as surprising. If we compare the sample measuring 1.13 inches thick with natural comb of the same thickness, we find that the latter is lighter by 5.35 grains. As the foundation itself weighed only 5.46 grains to the square inch, the indication is that the bees used as much wax from their own secreting, within

\footnotetext{
*Cheshire says "Bees very rareiy work more than half their cell walls out of even the stoutest sheets given them."-Bees aud Bee Culture, V. II., p. 216.
} 
.11 of a grain, as they would have used if no foundation had been given.

It was more difficult to get reliable results with the very light foundations where the amount of wax used was small but the results indicated that the wax was much better economized by the bees, and the comb was but slightly heavier than the natural, the difference being almost entirely in the somewhat heavier midrib.

One rather surprising result, which might turn out differently in a larger number of trials, was that the bees actually added more wax from their own secretions to the heary foundations in order to build comb of a given thickness than to light foundations to build to the same thickness.

The experiments at least showed that a large amount of wax in foundation does not economize the wax secretion of the bee much more than the wax of light foundations. And even when more wax is put in the foundation than is necessary to build the comb, the bees still add from 50 to 75 per cent as much as would be necessary to build the comb without foundation.

\section{A Few Miscellaneous Observations in Connection WITH THE WORK.}

The proportion of wax to honey in naturally made comb was found to vary between about 1 to 18 to 1 to 28, depending upon the thickness of the comb. The thinner the comb the larger the proportion of wax in it. This is because the bases of the cell walls are heavier than the outer portions and the midrib is as heavy in thin as in thick comb. Both the midrib and the cell walls of drone comb are heavier than the same parts of worker comb.

Wax seems to be used with best economy when the midrib of the foundation is of the thinness of the midrib of natural comb, and when there is a small, or at most a moderate amount of wax in the cell walls. 




Effects of artificial foundations on the

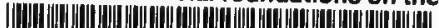

31924003211889

mann 


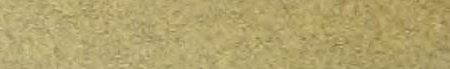

